\title{
Implementation of the law of the Eurasian Economic Union in national criminal law
}

\author{
Valery Lapshin ${ }^{1}$, and Nadezhda Kuznetsova ${ }^{2 *}$ \\ ${ }^{1}$ Ugra State University, 628012, 16 Chekhov str., Khanty-Mansiysk, , Russia \\ ${ }^{2}$ Vologda Institute of Law and Economics of the Federal Penitentiary Service of Russia, 160002, 2 \\ Shchetinina str., Vologda, Russia
}

\begin{abstract}
Currently, one can observe the process of active economic integration and cooperation, in the post-Soviet space. This is possible due to mutual economic and political interests, ensuring the protection of the interests of national producers, and obtaining competitive advantages of domestic goods in comparison with similar products of Western European and Asian manufacturers. The solution to all these problems is facilitated by the creation of a single international organization of the post-Soviet space - the Eurasian Economic Union (EAEU), the territory of its member states already constitutes a single customs space. Activities of the EAEU are associated with the adoption of a significant number of regulatory international legal acts. Implementation of these acts will be satisfactory only if the EAEU member states properly implement it in the national legislation. At present, several types of implementation of international law provisions in the national legislation of a particular country are distinguished in legislative activity: reception, transformation, referral, incorporation, ratification. Law enforcement practice also deserves special attention, including decisions of international courts binding in a single state. As a result of the study, the most preferred forms of implementation of the EAEU regulatory acts into the national law systems of its participants: Armenia, Belarus, Kazakhstan, Kyrgyzstan and Russia, were established. In addition, it was concluded that it is necessary to unify provisions of the criminal law of the listed states in terms of establishing liability for customs offenses. This decision will positively affect protection of both the interests of individual participants in economic relations and the economic security of each union state.
\end{abstract}

\section{Introduction}

The modern process of economic integration in the post-Soviet space is in fact characterized by significant difficulties associated with objectively existing contradictions in the field of protecting the national interests of respective states, despite the active work on formation of the international legal framework determined by individual researchers as "supranational law". Representatives of Russian business are interested, first of all, in obtaining additional guarantees and support in promoting their goods (works, services) on

*Corresponding author: a.copytowa@yandex.ru 
the international market. Business entities, residents of other countries of the former Soviet Union, see in Russia a significant labor market and sales of transit goods of foreign manufacturers, using various benefits and preferences provided by the relevant agreements on economic cooperation, on the elimination of a number of migration barriers, etc. Therefore, the existing issues of resolving existing contradictions complicate the development and strengthening of economic ties in the post-Soviet space.

An equally significant issue is the application of normative acts of the Eurasian Economic Union on the territory of all the member states, as well as the formation and implementation of the provisions of their national criminal law in terms of ensuring the proper protection of foreign economic relations. Therefore, solution of the problem of implementing the norms of international law of the EAEU into the national legislation of the union states is becoming quite important.

In accordance with the Basic Laws of the EAEU countries, the norms of international law as a general rule have greater legal force in comparison with the norms of national legislation. In particular, part 4 of Art. 15 of the Constitution of the Russian Federation determines that universally recognized principles and norms of international law, international treaties concluded by Russia with other states - representatives of the international community, are included in the Russian legal system. In case of collisions and contradictions, the rules of international rather than national law are applicable. Similar provisions are contained in the constitutions of all EAEU countries.

A rather complicated legal issue is the definition of criminal liability for acts committed in the process of foreign economic activity in the territory of a single economic space. As already noted, in accordance with the Treaty on the Eurasian Economic Union of 05.29.2014, criminal law regulation is not included in the competence of the bodies of the union, and therefore referred to the exclusive competence of the national legislator. However, all norms on foreign economic crimes are blanket, and the determination of legally significant features of their composition is carried out using the provisions of the EAEU international law. For this reason, it is already necessary to resolve the issue of formation of national criminal law in terms of determining the criminality and punishability of acts committed in the course of foreign economic activity on the territory of the EAEU states, as well as on how to implement the relevant provisions of the EAEU law in the national legislation of the Union states on liability for foreign economic crimes.

The purpose of the study is to justify the most acceptable forms of implementation of the EAEU legislation in the national legal systems of individual union states. In addition, it substantiates the need to adopt a model EAEU criminal law as a basis for unification of the criminal law of the EAEU member states on liability for economic crimes.

To achieve these goals in the research process, the following tasks were solved:

- an assessment is given of economic and political integration in the post-Soviet space;

- the rule-making activities of the EAEU bodies are studied;

- the types of implementation of the provisions of international regulatory legal acts in national legislation are analyzed;

- Ways of improving the law-making and law enforcement activities of the EAEU bodies were identified;

- the features of unification of the provisions of the criminal law of the EAEU member countries regarding the establishment of liability for economic crimes were found.

\section{Methods}

In the modern scientific literature, general issues of implementation of the provisions of international law in the legislation of a particular country are considered in sufficient detail. Relevant studies were conducted by V.A. Vdovin [1], T.I. Kurnosova [2], I.I. Lukashuk [3], 
E.A. Shahunyants [4] and other authors. Particular issues of correlation and harmonization of the provisions of the EAEU international law and the national legislation of the Union states were considered by V.F. Anisimov [5], A. Grigoryan [6], I.S. Iksanov, I.Yu. Kosyrev [7], N.E. Kotorova [8], D. Titov [9] and other researchers.

The presented study took place in several stages. At the first stage, a general assessment was given to the processes of economic integration in the post-Soviet space and the goals of creating the EAEU. For this, the analysis method was used, as well as the inductive method of cognition.

At the second stage, using the system-structural method of cognition, we studied the contents of each of the types of implementation of international law that are available in modern humanitarian science.

At the final third stage of the study, the dialectical method of cognition was used to identify preferred types of implementation of the EAEU normative acts in national legislation, as well as to formulate proposals on the creation of the EAEU Model Criminal Code to determine common principles about economic crimes. The need for this is substantiated through the creation of uniform rules for establishing and implementing responsibility on the territory of any EAEU member state for committing an economic crime. This part also used the method of analysis, the historical method of cognition.

All of these methods can be used for other studies purposed to identify the features of eliminating conflicts and contradictions between national and international law of the EAEU, including the regulation of liability for an economic crime.

\section{Results}

According to the results of this study, it was found that the most acceptable types of implementation of the provisions of the EAEU regulatory acts into the national legislation of the union states are reception and referral. In order to properly ensure the criminal legal protection of the interests of business entities engaged in economic activities in the customs territory of the EAEU, as well as the economic security of the EAEU member states, it is necessary to create a Model Criminal Code of the EAEU, which defines uniform conditions for the criminalization and penalization of economic crimes.

\section{Discussion}

In the modern science of international law, the content of implementation and the means of its implementation have not received an unambiguous interpretation. In accordance with the reference literature, the term "implementation" in relation to international law is interpreted as the actual implementation of international obligations at the domestic level. Implementation is carried out by transforming the content of international law into specially adopted regulations of a particular state. In a number of cases, nomes of international law become part of national legislation if the state recognizes as a special law on ratification the mandatory implementation thereof in the territory of its jurisdiction. Therefore, the authors are inclined to consider implementation as a process of perceiving the instructions to carry out any actions or refraining from carrying them out, provided for in international law, and their subsequent application in the territory of a sovereign state, and also to classify all the norms of international law as self-executable and non-self-executable, implemented depending on the content of national law.

A specific feature of international law is its actual inability to act as a regulator of public relations without exercising appropriate perception at the level of individual subjects of international relations, which are primarily states and state entities. Therefore, the quality of 
implementation of the norms of international law, the correct choice of means for its implementation will depend on the reality of the emergence and existence of legal relations determined by the norms of international acts, as well as the achievement of the ultimate goal of implementation, the full coherence of the national legislation of each of the participants in international relations with the relevant requirements of international legal acts.

The theory of international law also defines ways used for ensureing implementation of the provisions of international normative acts in the system of legislation of a particular state. These include: reception, transformation, referral, incorporation and ratification. At present, it is not possible to talk about a differentiated system of the listed methods, since various authors interpret their contents differently, up to defending the opinion about the substantial identity of some of the listed methods with the term "implementation" or, on the contrary, about the isolation of the legal content of each of the listed legal categories, and in some cases they do not recognize some of the listed methods for the implementation of international law in national legislation.

So, the reception is a reproduction of the content of a norm of international law in regulatory acts of domestic law. As a result of the use of the reception, the provisions of international law are accurately reproduced without any meaningful adaptation to national legal features, legal culture and the specifics of the language of legal presentation. According to some researchers, reception can be used both in the field of international law (for example, in the law of international treaties), and in relation to the norms of national foreign law, the rules of law that were developed in a different historical era, but have not lost their relevance in terms of regulation and (or) protective existing in the present time public relations.

For this reason, reception of law is possible only in cases of historical continuity, or subject to the similarity of legal cultures, socio-economic development and political structure of the respective states. All the above conditions for reception of the EAEU international law into the national legislation of the respective states, as we believe, are respected. Therefore, the reception of law, formed at the level of bodies of the Eurasian Economic Union, is one of the most convenient means of implementation in the national, including criminal, legislation of the union states.

The next method of implementation distinguished in the theory of international law is transformation. This method, according to experts, is designed to protect national legislation from the provisions of international law, which are alien in form and therefore not suitable for perception and execution on the sovereign territory of a particular state. Hence, transformation in the process of preparing the relevant regulatory acts of national legislation provides a summary of the provisions of international law in the form that is traditional for the legislation of the state - the subject of international relations.

With regard to the international law of the EAEU, transformation can hardly be considered as one of the main ways of its implementation. At the heart of the formation of the legislation of the EAEU member countries are the traditions of legislative technology laid down by the theory of Russian and Soviet law. The content of normative acts on the official websites of government bodies and institutions of all countries of the Eurasian Economic Union is presented (duplicated) in Russian. In this regard, one should not be afraid of a significant inconsistency in the form of presentation of normative material in the law of the EAEU, which, for technical and legal reasons, would be difficult to reproduce, interpret and apply in a single union state.

Referral as a way of implementing international law is a fairly common legislative technique. In the process of enforcement, the provisions of a normative act indicate that the provisions of another normative act must be taken into account. Therefore, in normative acts of national law, a reference can be used to indicate the relevant provisions of the 
EAEU regulatory acts, which are subject to application in the process of implementation of foreign economic relations. The value of this legislative technique lies in the ability to refuse to adopt special regulations, which, in fact, would duplicate the relevant provisions of the EAEU law. This ensures compliance with one of the basic rules of legal technology legislative savings of regulatory material, which simplifies interpretation and application of the regulatory act.

Given these circumstances, referral can also be recognized as one of the most effective ways to implement the EAEU law in the national legislation of its member countries. Regarding the formation of provisions on criminal liability for committing foreign economic socially dangerous infringements, the referral, in our opinion, is indispensable when indicating certain legally significant features of these crimes, the contents of which are disclosed at the level of the EAEU regulatory acts.

Incorporation is a way of implementing international law, when the state adopts a special regulatory act that promotes the application and enforcement of the provisions of the international normative act. Incorporation is applicable in cases where the norms of international law are quite abstract in nature and determine the general directions for the formation of interstate legal relations. Clarification of the material content, as well as all procedural issues of the implementation of these provisions are resolved at the level of a specially adopted normative act of national law ensuring the implementation of international law through incorporation. As an example of incorporation, one can cite the application on the territory of a single state of the provisions of international treaties on mutual legal assistance, on avoidance of double taxation, etc. The adopted norms of national legislation specify the relevant provisions of a normative act of an international treaty or agreement.

Finally, ratification as a general rule is the most common way of implementing international law into national legislation. Some authors consider ratification as one of the stages of the process of adoption by the state of obligations of international legal significance, since the fact of conclusion of an international agreement does not ensure the emergence of state obligations for its implementation until a law on ratification of the relevant provisions of international normative legislation is adopted ensuring its priority in legal force in comparison with normative acts of national law.

The significance of incorporation and ratification for the implementation of the EAEU law in the criminal law of the Union states is minimal due to the initial agreement of the EAEU member states on the exclusion of criminal law regulation from the sphere of regulatory activity of the EAEU bodies, and therefore regulatory acts determining the criminality and punishability of specific types of socially dangerous acts are not issued at the level of the EAEU bodies. For this reason, these methods of implementing the EAEU law are relevant only in terms of application of regulatory legislation in the field of foreign economic activity carried out in the single economic space of the EAEU member countries.

All of the above methods of implementing international law are varieties of exclusively law-making activities. However, some authors also identify law enforcement practice as a way of implementation, the peculiarities of law enforcement as a kind of way to clarify and adopt for implementation the provisions of a normative act of international law. We believe that this opinion can be supported, despite the fact that the solution proposed by the authors is in a slightly different plane of law. Indeed, the most flawless normative act of international law, the most effective ways of translating its content in national law, cannot actually guarantee the implementation and enforcement of relevant legal requirements.

Law enforcement practice is an indicator of how the norm of international law meets the needs and expectations of society in legal regulation and protection. And if the norm does not meet these requirements, does not protect public values, then its implementation in the territory of a particular state will be reduced only to a formal existence in the system of 
national law. Law enforcement adapts the content of a normative act to the prevailing conditions, and also ensures the consistency of international law having the status of selfexecuting, and national law determining the forms of fulfillment of obligations enshrined at the level of international treaties and agreements. Law enforcement practice determines the legal norm that is applied in a specific legal relationship and thus solves the issue on the basis of a combination of provisions of international and national law, taking into account the existing needs of society and the experience gained in the process of legal regulation.

With regard to the EAEU law, it is too early to single out the prevailing forms of practical implementation of its provisions at the national level, since the "supranational" law itself cannot be recognized as finally formed and constituting an orderly system of institutions of customs and other foreign economic regulation and protection. However, an understanding of the need for consistency in the content of the EAEU regulatory acts and the corresponding provisions of the national legislation of the Union states, as well as their uniform application throughout the Eurasian economic space, is recognized by all parties to the Agreement of 05/29/2014. This is confirmed by the creation of a permanent EAEU Court aimed to ensure uniform application by both EAEU Member States and EAEU bodies of the EAEU Treaty, international treaties and agreements concluded within the framework of the EAEU activities, international treaties and agreements concluded with third countries (item 2 of the Statute of the Court of the Eurasian Economic Union;. Annex №2 to the Contract from 29.05.2014).

As follows from the above Statute on the EAEU Court, its competence does not include issues of determining measures of responsibility for violation of the EAEU legislation on foreign economic activity by individual citizens, as a result the implementation of criminal liability is also the exclusive competence of national judicial system of the corresponding union state.

But, despite the exclusivity of state competence in determining the content of national criminal legislation, it seems that the modern legislation of the EAEU cannot be considered final. As follows from the general theory of law, any system of normative requirements can be recognized as formed only in cases where it includes both regulatory and protective mechanisms. The absence of norms ensuring the protection of existing social relations significantly complicates the process of legal regulation of these relations leading to the impossibility of their implementation. Given these circumstances, it can be argued that there is a need to adopt a regulatory act of the EAEU defining model forms of criminal liability for committing foreign economic crimes in the territory of a single economic space - the sovereign territories of the EAEU member states.

This decision is necessary to indicate legal standards and rules for determining responsibility for crimes committed in the field of foreign economic activity for national criminal laws. Unification in this part will provide unified approaches to determining the conditions for criminal liability, qualification of criminal acts, differentiation and individualization of responsibility for their commission throughout the EAEU, i.e. compliance with the principles of legality, equality of citizens before the law and justice.

Development and adoption of the EAEU model act on criminal liability for foreign economic crimes should be carried out on the basis of conceptual provisions on the unification of the criminal laws of the EAEU member states determining the principles of liability for foreign economic violations committed in the territory of the EAEU or outside it, but against the interests of the EAEU, and also determining the rules for the provision of legal assistance to all states that are part of the EAEU, to prevent illegal external economic activities. 


\section{Conclusion}

Summing up the study of the indicated issues of implementation, we can draw the following conclusions: firstly, the goal of implementing the Eurasian Economic Union law in the national criminal law is the proper implementation of their obligations by its member countries, including ensuring proper protection of foreign economic relations. This can be done only with full compliance with the content of the EAEU law and the relevant norms of national legislation, as well as their uniform application on the territory of all union states.

The most effective means of implementing the EAEU law in the national criminal law are reception and referral. The reception is the most convenient and efficient with respect to the implementation of the provisions of normative acts related to the sources of the EAEU model criminal law, and the referral is the provisions of the EAEU regulatory legislation that determine the content of institutions and categories that have legal significance in qualifying foreign economic crimes. Transformation, incorporation and ratification cannot be considered as acceptable ways to implement the EAEU law in the national criminal law, since it is not the subject of normative activity of the bodies of the Eurasian Economic Union.

Secondly, the modern legislation of the Eurasian Economic Union cannot be recognized as final formed due to the lack of norms ensuring the protection of foreign economic and other relations arising in the process of the EAEU functioning. To ensure the unification of national criminal laws regarding liability for committing foreign economic crimes on the territory of a single economic space, it is necessary to adopt a regulatory act of the EAEU containing model norms on the types of 1) foreign economic crimes; 2) punishments and other measures of criminal law applicable to persons who are found guilty of the commission of these crimes. Ensuring the unification of national criminal laws through the reception of model provisions of the EAEU legislation on crime and the punishability of foreign economic crimes will also have a positive effect on the uniformity of their application on the territory of a single economic space.

The authors are deeply grateful to the leadership of Ugra State University and the Vologda Institute of Law and Economics of the Federal Penitentiary Service of Russia for the help and support provided in carrying out this study.

\section{References}

1. V. A. Vdovin, Implementation of international legal norms in the criminal law of the Russian Federation (2006)

2. T. I. Kurnosova, Implementation of international legal norms on war crimes and crimes against humanity in the Russian criminal law, (2015)

3. I. Lukashuk, International legal regulation of international relations (systematic approach), (1975)

4. E. A. Shahunyants, International legal obligations and domestic criminal law. Specialized information (1993)

5. V. F. Anisimov, Jurisprud. Pract. Bull. Nizhny Novgor. Acad. Ministr. Inter. Aff. Rus. $1,25-29(2018)$

6. Grigoryan, What benefits did the country receive from participating in the EAEU, https://sozh.info/kakie-vygody-poluchili-strany-ot-uchastiya-v-eaehs/

7. S. Iksanov, I. Yu. Kosyrev, Bull. Fin. Un. 5, 6-12 (2017)

8. N. E. Kotorva, Bull. Fin. Un. 5, 126-132 (2016)

9. D. Titov, Econ. Life, (2017)

10. S. N. Boldyrev, Philos. Law. 5, 27-30 (2014)

11. D. Yu. Goncharov, Lex Russica, 6, 75-89 (2015) 
12. A.V. Izmailov, Gaps Rus. legisl. 1, 149-150, (2008)

13. A. S. Giants, Law. J. High. Sch. Econ. 4, 152-166 (2016)

14. M. A. Rylskaya, A. Yu. Kozhankov, O. G. Bobrova, Fin. Theor. Pract. 4, 88-103 (2018)

15. S.V. Tkachenko, Cult. Manag. Econ. Law. 4, 10-15 (2017)

16. Yu.V. Truntsevsky., A. A. Tsvetkov, Int. Publ. Priv. Law. 2, 28-33 (2005).

17. Y. V. Truntsevsky, I. I. Lukiny, A.V. Sumachev, A.V. Kopytova, MATEC Web of Conferences 170, 01067 (2018) DOI: 10.1051/matecconf/201817001067

18. I. Skvortsova, R Latyshev, Y. TruntsevskyE3S Web of Conferences, 110, 02167 (2019), DOI: $10.1051 / \mathrm{e} 3$ sconf/201911002167

19. N. Semeryanova, A Kopytova, L.Dolnikova, V. Morozkov, 2019, MATEC Web of Conferences 239,04008, DOI: 10.1051/matecconf/201823904008

20. V. Lez'Er, , N Semerianova,. Et al. E3S Web of Conferences 2019, 110,02093, DOI: 10.1051/e3sconf/201911002093

21. U. Filatova, N. Semeryanova..et al. 2019, E3S Web of Conferences 91,08071, DOI: 10.1051/e3sconf/20199108071

22. R. Kolobov, U. Filatova, et al. E3S Web of Conferences 2019, 110,02095, DOI: 10.1051/e3sconf/201911002095

23. V. Lez'Er, , Semeryanova, N., Kopytova, A., I. Kvach, E3S Web of Conferences, 2019, 110,02094, DOI: $10.1051 / \mathrm{e} 3$ sconf/201911002094

24. N. Semeryanova., O. Fedorenko,. A .Kopytova,. 2018, MATEC Web of Conferences 239,04013, DOI: 10.1051/matecconf/201823904013

25. D. Izvin, V. Lez'Er, A. Kopytova, MATEC Web of Conferences 170, 01065 (2018) DOI: $10.1051 /$ matecconf $/ 201817001065$

26. U. Filatova, N. Semeryanova..et al2019, E3S Web of Conferences 91,08064, DOI: $10.1051 / \mathrm{e} 3$ sconf $/ 20199108064$ 